\title{
The effect of previous cropping on weeds of winter wheat
}

\author{
Erzsébet NÁDASY - Katinka BOLLA - György PÁSZTOR \\ University of Pannonia, Georgikon Faculty, Hungary, Keszthely, Deák F. utca 16. \\ E-mail: nadasyne@georgikon.hu
}

Keywords: weeds, winter wheat, previous crop

\section{Introduction}

Weed flora of winter wheat is determined by previous cropping, because every crop can propagate the own weed species. It is consequence of demanding similar ecological factors, the same life form and biology of crops and weeds, moreover the herbicide application (Hunyadi et al., 2011). In consequence of this, one of the disadvantages of monoculture is propagation of noxious weeds in cultivated plant. Besides, cultivated plant can appear in the next crop as a culture-weed. Crop rotation is not eliminate the weed damage, but helps to avoid strong infection, and unilateral changing of weed flora (Árendás et al., 2007). We must make weed survey regularly to identify weed species, and abundance, moreover growing stage of weeds in the fields. The most important weed species of winter wheat are winter annuals and some perennials (Novák et al., 2009, 2011, Gyulai, 2013).

\section{Materials and methods}

We made weed survey in 2017 on the winter wheat fields of Agro-Balaton Ltd. in Balatonszárszó, Szólád and Teleki near the lake Balaton. We examined two winter wheat varieties: Antonius, which is a middle ripening, and NS 40S, which is an early-ripening variety. We studied the weeds after four preceding crops, which were winter wheat, oilseed rape, sunflower and maize. We made weed survey two times, in March (24-26. 03.) first and after in April (20-22. 04.) with Balázs - Ujvárosi weed survey method. The parcels area was 5 ha in case of all previous crops and two varieties in three replications. The sampling area was $4 \mathrm{~m}^{2}$ on every parcels in four replications. We identified weed species found in sampling areas and estimated the weed coverage (\%).

\section{Results and discussion}

The most important weed species on the fields we found in the springtime were autumn annual weeds, as Stellaria media, Capsella bursa-pastoris, Veronica hederifolia Consolida regalis, Consolida orientalis, Viola arvensis, Centaurea cyanus. At the second time also appeared Sinapis arvensis, and Raphanus raphanistrum and started the germination of summer annuals, as Bilderdykia convolvulus, Cannabis sativa and Helianthus annuus. Between perennial weeds, we detected Convolvulus arvensis and Cirsium arvense in the sampling areas. Monocotyledonous weeds did not germinated in March and April yet.

In March, weed density was very low in all sampling areas, and in April became higher of course. The average weed coverage after different previous plants in March and April you can see in Table 1 and 2.

The overgrown with weeds in a field strongly depend on rainfall of October and November and temperature too. Between favourable circumstances, $T_{1}$ and $T_{2}$ weeds germinate in autumn. The rainfall in 2016 was significantly less, than the average of the years, similarly in January and March of 2017. It was the reason why only a few germinated weeds with low coverage we surveyed in Marc in the parcels. 
Table 1.: The average weed coverage on winter wheat fields after different first crops in March

\begin{tabular}{|c|c|c|}
\hline & \multicolumn{2}{|c|}{ weed coverage \% } \\
\hline Previous crop & NS 40 & Antonius \\
\hline Winter wheat & 1.96 & 1.56 \\
\hline Oilseed rape & 0.40 & 0.28 \\
\hline sunflower & 0.12 & 0.14 \\
\hline maize & 0.25 & 0.53 \\
\hline
\end{tabular}

Table 2.: The average weed coverage on winter wheat fields after different first crops in April

\begin{tabular}{|c|c|c|}
\hline & \multicolumn{2}{|c|}{ weed coverage \% } \\
\hline Previous crop & NS 40 & Antonius \\
\hline Winter wheat & 7.30 & 9.45 \\
\hline Oilseed rape & 5.49 & 3.40 \\
\hline sunflower & 3.29 & 3.29 \\
\hline maize & 3.50 & 2.89 \\
\hline
\end{tabular}

\section{Conclusions}

Weed flora of the winter wheat fields after different preceding crop was different. Winter wheat and oilseed rape are autumn sowing plants, so weeds of the parcels followed these crops, proved similar, but followed sunflower or maize were different, because of the main weed species of these crops are $\mathrm{T}_{4}$ species.

The species richness and abundance were least when the wheat follows maize, in consequence of successful weed control and herbicide usage.

We did not detected significant differences between weed coverings of examined wheat varieties.

Our experiment justified that previous crop has a considerable role in forming of weed flora and weed coverage of following crop.

\section{References}

Árendás T., Láng L., Bódis P., Berzsenyi Z. (2007): Búzaminőség és agrotechnika. Agrofórum. 18. 10-13.

Hunyadi K., Béres I., Kazinczi G. (2011): Gyomnövények, gyombiológia, gyomirtás. Mezőgazda kiadó. Budapest.

Gyulai B. (2013): Kalászos Gabonák Gyomirtása. Agrárágazat.14. 42-44.

Novák R., Danczai I., Szentey L., Karamán J. (2009): Magyarország szántóföldjeinek gyomhelyzete. Ötödik Országos Szántóföldi Gyomfelvételezés (2007-2008) FVM, Budapest.

Novák R., Dancza I., Szentey L., Karamán J. (2011): Az ötödik országos gyomfelvételezés Magyarország szántóföldjein. Vidékfejlesztési Minisztérium Élelmiszerlánc-felügyeleti Főosztály Növény- és Talajvédelmi Osztály, Budapest. 